\title{
Performance of MALDI Biotyper for Species Identification of Carbapenem-Resistant Enterobacteriaceae by Media Types and Incubation Time
}

Young Eun Cho, Byoung Hu Choi, Jeonghyun Chang, Heungsup Sung, and Mi-Na Kim

Department of Laboratory Medicine, Asan Medical Center, University of Ulsan College of Medicine, Seoul, Korea

Corresponding author: Mi-Na Kim

Department of Laboratory Medicine, Asan Medical Center, University of Ulsan College of Medicine, 88 Olympic-ro 43-gil, Songpa-gu, Seoul 05505, Korea Tel: +82-2-3010-4511

Fax: +82-2-478-0884

E-mail: mnkim@amc.seoul.kr

pISSN: 2384-2458

elSSN: 2288-7261

\begin{abstract}
Background: This study was conducted to evaluate the impact of the media type used for direct identification of colonies on the surveillance culture of carbapenem-resistant Enterobacteriaceae (CRE) by matrix assisted laser desorption ionization-time of flight mass spectrometry (MALDI-TOF MS).

Methods: CRE surveillance culture isolates were subjected to species identification using the MALDI Biotyper (Bruker Daltonics, Germany) for 2 months starting in March 2017. Four types of media were evaluated: blood agar (BA), Mueller Hinton agar (MH), MacConkey agar (Mac), and MacConkey agar containing imipenem of $1 \mu \mathrm{g} / \mathrm{mL}$ (IMP-Mac). CRElike colonies on IMP-Mac and their subculture colonies on the other media were tested after overnight incubation and extended incubation for one additional day. The percent identification and score value were analyzed for each media types and incubation time when the identification was correct at the genus level.

Results: A total of 117 isolates were identified as 84 Klebsiella pneumoniae, 12 Escherichia coli, 9 Enterobacter cloacae, 5 Klebsiella oxytoca, 4 Enterobacter aerogenes, and 2 Raoultella ornithinolytica. The successful identification rates (SIR) for BA and $\mathrm{MH}$ were $98.3 \%$ and 97.4\% $(P=0.9)$, respectively, while those for Mac and IMP-Mac were $82.1 \%(P<0.001)$ and $70.9 \%(P<0.001)$, respectively. After extended incubation, SIRs were decreased to $96.6 \%$, 96.6\% $(P=1.0), 61.5 \%(P<0.001)$, and $58.1 \%(P<0.001)$ on BA, MH, Mac, and IMP-Mac, respectively. The average score values were significantly lower for Mac $(2.017 \pm 0.22)$ and IMP-Mac $(1.978 \pm 0.24)$ than for BA $(2.213 \pm 0.16)(P<0.001)$.

Conclusions: The low performance of the MALDI Biotyper applied directly to the colonies grown on Mac or IMP-Mac indicates that subculture on BA or MH is preferable before identification by MALDI-TOF MS.
\end{abstract}

(J Lab Med Qual Assur 2018;40:155-160)

Key Words: Carbapenem-resistant Enterobacteriaceae, Surveillance, MALDI-TOF, Media type, Incubation time

Received January 3, 2018, Revision received July 10, 2018, Accepted August 2, 2018

\section{INTRODUCTION}

Carbapenem-resistant Enterobacteriaceae (CRE) represent a serious growing threat to public health in Korea. Serious Infections with CRE are difficult to treat or non-treatable, and thus are associated with high mortality rates. Carbapenemase-mediated CRE is unique because of its capacity for horizontal transmission via a plasmid, by which carbapenem-resistance increases rapidly and crosses the species barrier [1]. In a previous study of five Korean university hospitals, ertapenem susceptibilities were 99.5\% among Escherichia coli and 94.0\% among Klebsiella pneumoniae in 2015 [2]. CRE has been designated as a legally notifiable disease since October 


\section{Journal of LABORATORY MEDICINE and QUALITY ASSURANCE}

\section{Young Eun Cho et al • MALDI Biotyper Identification of CRE}

2010, and Korea Centers for Disease Control and Prevention (KCDC) implemented a laboratory-based monitoring system in representative regional hospitals to collect and genotype CRE and CPE (Carbapenemaseproducing Enterobacteriaceae) nationwide [1]. CRE has been considered as a group III notifiable disease since June 2017, and all CRE cases and patients harboring CRE should be reported to the KCDC [1].

CRE surveillance culture is an essential element in the control and prevention of CRE infection [3]. Because $\mathrm{CRE}$ infection rates have increased since the first four cases of NDM-producing $K$. pneumoniae were found at our hospital in 2010 [4], CRE surveillance culture has become a routine practice in many clinical microbiology laboratories in Korea. To accelerate the turn-around time of CRE surveillance culture, matrix assisted laser desorption ionization-time of flight mass spectrometry (MALDI-TOF MS, MALDI-TOF) was recently introduced for direct species identification of colonies on selective agar [5-7]. However, species identification of CRE grown on MacConkey agar containing imipenem (IMP-Mac) failed biochemical identification tests in this hospital.

This study was performed to evaluate the impact of the media type on species identification using MALDI-TOF in CRE surveillance cultures. The influence of colony aging on species identification was also measured for incubation times of 1 and 2 days.

\section{MATERIALS AND METHODS}

\section{Specimens}

For 2 months, March and April 2017, four types of media were evaluated: blood agar (BA; KoMed, Seongnam, Korea), Mueller Hinton agar agar $(\mathrm{MH}$, KoMed), MacConkey agar (Mac, KoMed), MacConkey agar containing imipenem of $1 \mu \mathrm{g} / \mathrm{mL}$ (IMP-Mac). The samples subjected to CRE surveillance culture were inoculated on IMP-Mac and pink colonies were considered as CRE-likely colonies after overnight incubation at $36^{\circ} \mathrm{C} \pm$ $1^{\circ} \mathrm{C}$. Because routine practices in the laboratories use extended culture at room temperature to detect colonies in the case of holiday, the incubation was extended for one additional day at room temperature. All pink colonies on IMP-Mac were consecutively collected and subcultured on BA and Mac plates. Disk diffusion tests were conducted on $\mathrm{MH}$ agar. The colonies on each media type were tested for species identification using a MALDI biotyper (Bruker Daltonics, Bremen, Germany) and MicroScan NC72 panel (Beckman Coulter, Brea, CA, USA).

\section{MALDI-TOF Identification}

The colonies on each agar plate were directly prepared for MALDI-TOF identification. Briefly, a single colony was picked using a wooden toothpick and gently smeared onto a polished steel target plate. The spots were then overlaid with $1 \mu \mathrm{L}$ of IVD matrix solution (Bruker Daltonics) consisting of $47.5 \%$ deionized water, 50\% acetonitrile (Sigma-Aldrich, St. Louis, MO, USA) and 2.5\% trifluoroacetic acid (Sigma-Aldrich) and allowed to dry. The MALDI biotyper operation was conducted according to the manufacturer's instructions and species identification was based on Bruker Taxonomy with Mass Spectrometry Profiling. According to the manufacturer's instructions, the identification results with score values $\geq 1.7$ were considered reliable at the genus level. The correct identification was considered as showing consistent with results with MicroScan NC72 or Klebsiella oxytoca in MicroScan NC72 for Raoultella ornithinolytica identified by Biotyper. The successful identification rates (SIRs) and score values of the identification results were analyzed for each media type and incubation time.

\section{Statistical Analysis}

The SIRs of each media type were compared by chisquare tests. The score values of each specimen resulting in correct identifications were compared by paired t-test. Analysis was conducted using PASW SPSS ver. 18.0 software (SPSS Inc., Chicago, IL, USA). P-value of $<0.05$ was considered statistically significant.

\section{RESULTS}

A total of $117 \mathrm{CRE}$ were detected, including $84 \mathrm{~K}$. pneumoniae, 12 Escherichia coli, 9 Enterobacter cloacae, 


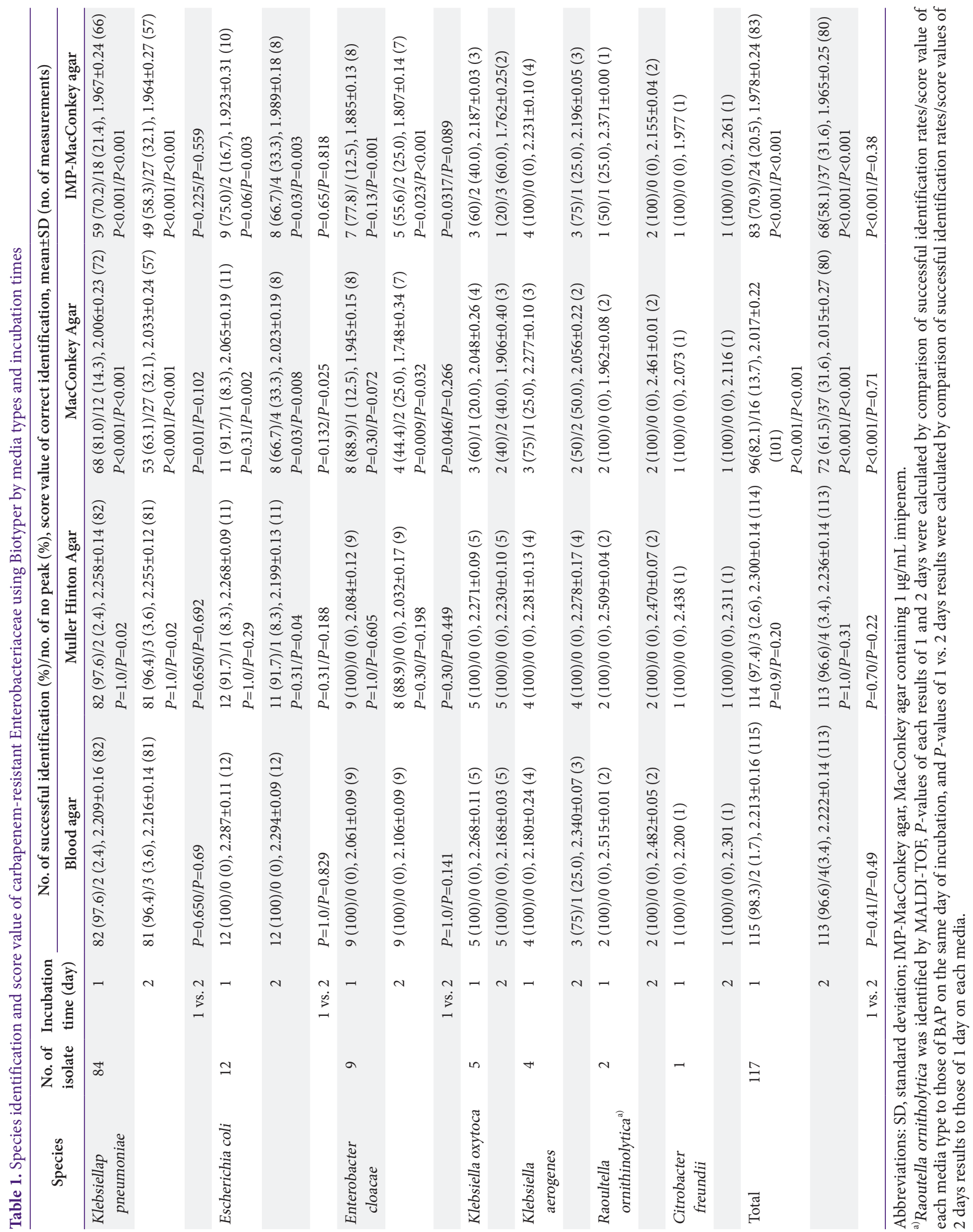




\section{Journal of LABORATORY MEDICINE and QUALITY ASSURANCE}

\section{Young Eun Cho et al • MALDI Biotyper Identification of CRE}

5 K. oxytoca, 4 Klebsiella aerogenes, 2 R. ornithinolytica, and 1 Citrobacter freundii. The MALDI-TOF identification results are shown in Table 1 . At overnight incubation, 98.3\% of isolates were correctly identified from the colonies on $\mathrm{BA}, 97.4 \%$ on $\mathrm{MH}(P=0.9), 82.1 \%(P<0.001)$ on MAC, and $70.9 \%(P<0.001)$ on IMP-MAC. After 2 days of incubation, the SIRs were decreased to $61.5 \%(P<0.001)$ on MAC and 58.1\% $(P<0.001)$ on IMP-MAC, but not on BA and on $\mathrm{MH}$ which showed values of $96.6 \%$ and $96.6 \%$, respectively. Unsuccessful identification mainly resulted from the lack of a peak, and the number of samples without peaks was increased after 2 days of incubation: 2 to 4 in BA, 3 to 4 in MH, 16 to 37 in Mac, and 24 to 37 in IMP-Mac (Table 1). The average score values for correctly identified specimens were significantly lower for Mac (2.017 \pm $0.22, P<0.001)$ and IMP-Mac $(1.978 \pm 0.24, P<0.001)$, while there was no significant difference between those for $\mathrm{MH}(2.300 \pm 0.14)$ and BA (2.213 \pm 0.16$)$. After 2-day incubation, the score values were slightly lower for each media type than those after day 1, but the differences were not significant among the specimens identified correctly except for $E$. coli on Mac and E. cloacae on IMPMac (Table 1). Among species for which 4 or more isolates were examined in this study, identification performance of the Biotyper was significantly lower when colonies grown on Mac or IMP-Mac were used, except for E. cloacae. The SIRs of colonies grown on Mac were further decreased by colony aging, except for $E$. coli, while those grown on BA and $\mathrm{MH}$ were not (Table 1 ).

\section{DISCUSSION}

In this study, SIRs were significantly lower for colonies grown on Mac compared to those grown on BA and $\mathrm{MH}$. The identification rate was further decreased when colonies on IMP-Mac were used. Because microbial identification by MALDI-TOF is based on unique protein signatures, certain media types and supplements may interfere with identification $[6,8,9]$. In a previous study, the type of media was found to affect the identification performance of MALDI-TOF MS for enteric gram-negative rods (EGNR), while growth on Mac showed similar performance as growth on BA, even when using the direct colony method [10]. Pseudomonas species are affected by growth on Mac more significantly when using the direct method described in the previous study. The reason for the difference in SIRs between media is unclear. The type of media is thought to affect the cell wall condition, making the colonies more mucoid in Pseudomonas species and affecting identification performance using the direct method [11]. This explanation may also apply to EGNR such as $K$. pneumoniae, which shows the greatest mucoid character and is the most prevalent CRE. Pigmented media such as Mac may affect protein spectral profiles, as has been observed for fungal pigments [12]. Additionally, bile salts in Mac may block ionization effects during examination [11]. In conclusion, species identification of EGNR by MALDI-TOF MS using the direct method was affected by the type of media used; growth on BA and $\mathrm{MH}$ is preferred to growth on Mac and IMP-Mac.

Colony aging also affected the success rate of identification when the colonies were grown on Mac. Colony aging from 5 to 48 hours did not impact identification performance [11]. Thus, very short-term incubation of 4 hours on solid media is sufficient to identify gram-negative rods, and further extending the incubation time does not improve SIR using MALDI-TOF [13]. Although the score value of correctly identified specimens did not change significantly with colony aging, the number of isolates showing no peak was significantly increased (Table 1). The effects of colony aging on $\mathrm{BA}$ and $\mathrm{MH}$ were not significant regardless of species, while results from Mac or IMP-Mac yielded lower confidence scores after 2 days of incubation compared to 1 day of incubation among $E$. cloacae and $K$. oxytoca. The bile salts present in Mac may interfered with the ionizing process because Hektoen Enteric agar or SalmonellaShigella agar containing more bile salts showed lower confidence scores than MAC or xylose lysine deoxycholate agar [11]. The effect of aging on E. coli was lower on MAC than on $K$. pneumoniae when using the direct method [11]. This suggests that interference is species-dependent. Aging on Mac may cause more interference when using MALDI-TOF for identification than that when using the direct method. Considering that CRE surveillance 


\section{Journal of LABORATORY MEDICINE and QUALITY ASSURANCE}

\section{Young Eun Cho et al • MALDI Biotyper Identification of CRE}

culture is not considered as an urgent condition in most clinical laboratories, colony reading is often delayed during weekends or holidays. The aging effect on selective agar may be a significant limitation in the application of MALDTOF to identify colonies on MAC or IMP-MAC.

A significant limitation of in this study was the small sample size, which did not include all common species of CRE. However, K. pneumoniae is the most prevalent species among CRE in Korea and showed a significant difference by media type and colony aging. The results demonstrated that growth on IMP-Mac certainly significantly reduces the ability of MALDI-TOF to identify CRE. In conclusion, for reliable species identification of CRE grown on IMP-Mac, a disk diffusion set on $\mathrm{MH}$ should be applied when using the direct method with MALDI-TOF. Further evaluation of larger sample sizes and a greater number of species is required to generalize these conclusions.

\section{REFERENCES}

1. Lee HJ, Lee DG. Carbapenem-resistant Enterobacteriaceae: recent updates and treatment strategies. J Korean Med Assoc 2018;61:281-9.

2. Jeong SH, Kim HS, Kim JS, Shin DH, Kim HS, Park MJ, et al. Prevalence and molecular characteristics of carbapenemase-producing Enterobacteriaceae from five hospitals in Korea. Ann Lab Med 2016;36:529-35.

3. Kim KR, Lee JY, Park HY, Kwak SH, Lim YJ, Hong MJ, et al. Clearance rate of carbapenemase-producing Enterobacteriaceae carriage among hospitalized patients. Infect Control Hosp Epidemiol 2015;36:1361-2.

4. Yoon EJ, Yang JW, Kim JO, Lee H, Lee KJ, Jeong SH. Carbapenemase-producing Enterobacteriaceae in South Korea: a report from the National Laboratory Surveillance System. Future Microbiol 2018;13:771-83.

5. Bizzini A, Greub G. Matrix-assisted laser desorption ionization time-of-flight mass spectrometry, a revolution in clinical microbial identification. Clin Microbiol Infect 2010;16:1614-9.

6. Clark AE, Kaleta EJ, Arora A, Wolk DM. Matrix-assisted laser desorption ionization-time of flight mass spectrometry: a fundamental shift in the routine practice of clinical microbiology. Clin Microbiol Rev 2013;26:547-603.

7. De Carolis E, Vella A, Vaccaro L, Torelli R, Spanu T, Fiori B, et al. Application of MALDI-TOF mass spectrometry in clinical diagnostic microbiology. J Infect Dev Ctries 2014;8:1081-8.

8. Seng P, Drancourt M, Gouriet F, La Scola B, Fournier $\mathrm{PE}$, Rolain JM, et al. Ongoing revolution in bacteriology: routine identification of bacteria by matrix-assisted laser desorption ionization time-of-flight mass spectrometry. Clin Infect Dis 2009;49:543-51.

9. Fenselau C, Demirev PA. Characterization of intact microorganisms by MALDI mass spectrometry. Mass Spectrom Rev 2001;20:157-71.

10. Anderson NW, Buchan BW, Riebe KM, Parsons LN, Gnacinski S, Ledeboer NA. Effects of solid-medium type on routine identification of bacterial isolates by use of matrix-assisted laser desorption ionization-time of flight mass spectrometry. J Clin Microbiol 2012;50:1008-13.

11. Reich M, Bosshard P, Stark M, Beyser K, Borgmann S. Species identification of bacteria and fungi from solid and liquid culture media by MALDI-TOF mass spectrometry. J Bacteriol Parasitol 2013;S5:002. https://doi. org/10.4172/2155-9597.S5-002.

12. Buskirk AD, Hettick JM, Chipinda I, Law BF, Siegel PD, Slaven JE, et al. Fungal pigments inhibit the matrixassisted laser desorption/ionization time-of-flight mass spectrometry analysis of darkly pigmented fungi. Anal Biochem 2011;411:122-8.

13. Idelevich EA, Schule I, Grunastel B, Wullenweber J, Peters G, Becker K. Rapid identification of microorganisms from positive blood cultures by MALDI-TOF mass spectrometry subsequent to very short-term incubation on solid medium. Clin Microbiol Infect 2014;20:1001-6. 
Journal of LABORATORY MEDICINE and QUALITY ASSURANCE

Young Eun Cho et al • MALDI Biotyper Identification of CRE

배지종류와 배양시간에 따른 카바페넴내성 장내세균의 MALDI Biotyper 동정능 평가

조영은・최병후・장정현・성흥섭・김미나

울산대학교 의과대학 서울아산병원 진단검사의학과

배경: $\mathrm{T}$ 카바페넴내성 장내세균(carbapenem-resistant Enterobacteriaceae, CRE)의 감시배양배지 에서 자란 집락을 직접 matrix assisted laser desorption ionization-time of flight mass spectrometry (MALDI-TOF)를 이용하여 동정할 때 배지종류와 배양시간에 따른 동정능을 평가하였다.

방법: 2017년 3월부터 2달간 의뢰된 CRE 감시배양에서 imipenem0 $1 \mu \mathrm{g} / \mathrm{mL}$ 첨가된 MacConkey agar (IMP-Mac)에서 양성으로 선별된 집락들을 MALDI Biotyper (Bruker Daltonics, Germany) 를 이용하여 직접 동정하였다. 또한 혈액한천배지(blood agar, BA), Mueller Hinton agar $(\mathrm{MH})$, MacConkey agar (Mac)에 계대배양하여 각각의 배지에 하룻밤 배양한 것과 이틀째까지 배양한 것 을 비교평가하였다. 속수준까지 동정에 성공한 경우 동정률과 동정한 스코어 값을 분석하였다.

결과: 총 117개 검체에서, Klebsiella pneumoniae 84개, Escherichia coli 12개, Enterobacter cloacae 9개, Klebsiella oxytoca 5개, Enterobacter aerogenes 4개, Raoultella ornithinolytica 2개가 동정되었다. Mac와 $\mathrm{MP}-\mathrm{Mac}$ 의 동정률이 82.1\% ( $P<0.001)$ 와 70.9\% ( $P<0.001)$ 였던 반면, $\mathrm{BA}$ 와 $\mathrm{MH}$ 의 동정률은 각각 $98.3 \%, 97.4 \%(P=0.9)$ 였다. 배양 이틀째 BA, MH, Mac과 IMP-Mac 배지별 동 정률은 96.6\%, 96.6\% ( $P=1.0), 61.5 \%$ ( $P<0.001)$, 58.1\% ( $P<0.001)$ 로 Mac과 MP-Mac에서 유

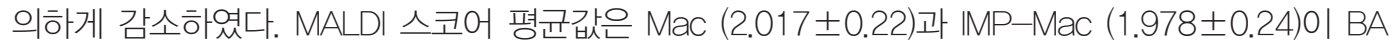
(2.213 \pm 0.16$)(P<0.001)$ 에 비해 유의하게 낮았다.

결론: Mac 또는 $\mathrm{MP}-\mathrm{Mac}$ 에서 직접 MALDI Biotyper로 동정하는 경우 동정률이 낮았다. 이는 MALDI-TOF 동정 전 BA 또는 MH에서 하룻밤 계대배양함으로써 동정 정확도를 높일 수 있다는 것 을 나타낸다.

(J Lab Med Qual Assur 2018;40:155-160)

교신저자: 김미나

우)05505 서울시 송파구 올림픽로43길 88, 울산대학교 의과대학 서울아산병원 진단검사의학과

Tel: 02)3010-4511, Fax: 02)478-0884, E-mail: mnkim@amc.seoul.kr 